\title{
Description of Bacillus azotoformans sp. nov.
}

\author{
F. PICHINOTY, ${ }^{*}$ H. DE BARJAC, ${ }^{2}$ M. MANDEL, ${ }^{3}$ AND J. ASSELINEAU ${ }^{4}$ \\ Centre de Biochimie et de Biologie Moléculaire, Unité No. 5, UER Scientifique de Luminy, Marseille, \\ France ${ }^{1}$; Service de Lutte Bactériologique contre les Insectes, Institut Pasteur, Paris, France ${ }^{2}$; The \\ University of Texas System Cancer Center, M. D. Anderson Hospital and Tumor Institute, Houston, Texas \\ $77030^{3}$; and Centre de Recherche de Biochimie et de Génétique Cellulaires, Centre National de la Recherche \\ Scientifique, 31062 Toulouse, France ${ }^{4}$
}

The name Bacillus azotoformans (ex Pichinoty, de Barjac, Mandel, Greenway, and Garcia 1976) is revived. Strains of this species are motile and produce terminal or subterminal oval endospores in swollen sporangia. Nitrate, nitrite, and nitrous oxide are denitrified with production of nitrogen. The guanine-pluscytosine content of the deoxyribonucleic acid of this organism is $39.8 \pm 1.2 \mathrm{~mol} \%$ (mean \pm standard deviation). The type strain is ATCC 29788 (= CCM $2849=$ CIP R925).

The name Bacillus azotoformans Pichinoty, de Barjac, Mandel, Greenway, and Garcia 1976 does not appear on the Approved Lists of Bacterial Names (9), although it was effectively published (6) and a type strain was designated (7). The purpose of this report is to revive the name Bacillus azotoformans and to effect its valid publication. Although this species has been described previously (6), we provide a formal description, including formerly unpublished fatty acid and phospholipid compositions.

Fatty acid and phospholipid composition studies were done by using strains 1,13 , and 30 (7). These strains were grown for $24 \mathrm{~h}$ at $32^{\circ} \mathrm{C}$ in yeast extract-salts liquid medium; this medium was made by combining $4 \mathrm{~g}$ of yeast extract (Institut Pasteur, Lille, France), $3.575 \mathrm{~g}$ of $\mathrm{Na}_{2} \mathrm{HPO}_{4} \cdot 12 \mathrm{H}_{2} \mathrm{O}, 0.98 \mathrm{~g}$ of $\mathrm{KH}_{2} \mathrm{PO}_{4}, 0.03 \mathrm{~g}$ of $\mathrm{MgSO}_{4} \cdot 7 \mathrm{H}_{2} \mathrm{O}, 0.5 \mathrm{~g}$ of $\mathrm{NH}_{4} \mathrm{Cl}, 0.2 \mathrm{ml}$ of a solution containing calcium and various heavy metals chelated with ethylenediaminetetraacetate (8), and distilled water to a volume of 1 liter. Under these conditions, poly- $\beta$-hydroxybutyrate is not synthesized. Cells were collected by centrifugation, washed with distilled water, and freeze-dried. The total free lipids were extracted with chloroform-methanol $(2: 1, \mathrm{vol} / \mathrm{vol})$. After evaporation of the solvents in a vacuum, the residue was extracted with ether. Silica Gel G plates (E. Merck AG, Darmstadt, Germany) were spotted with approximately $10 \mu \mathrm{g}$ of each sample and then developed in ascending fashion by using a solution containing petroleum ether $\left(\right.$ bp $\left.50^{\circ} \mathrm{C}\right)$ and diethyl ether $(4: 1$, vol $/ \mathrm{vol})$. Staining of the developed plates with Rhodamine B revealed no more than traces of triglycerides.
Further development with chloroform-methanol-water $(65: 25: 4, \mathrm{vol} / \mathrm{vol})$ and successive staining were performed with ninhydrin and Dittmer reagents. For fatty acid gas chromatography, the lipids were saponified in $5 \%(\mathrm{wt} / \mathrm{vol}) \mathrm{KOH}$ that was dissolved in $33 \%$ ( $\mathrm{vol} / \mathrm{vol})$ aqueous methanol at $100^{\circ} \mathrm{C}$ for $90 \mathrm{~min}$. Fatty acids were methylated by reacting them with diazomethane in diethyl ether and then injected into a 3-m glass column containing $1 \%$ OV-1 on Chromosorb W. A model G-30 gas chromatography (Girdel, Suresne, France) was used, and a temperature increase from 130 to $250^{\circ} \mathrm{C}$ was programmed at $3^{\circ} \mathrm{C} / \mathrm{min}$. Peaks were identified by adding internal standards and also by comparison with the methyl esters of the fatty acids extracted in a similar manner from Streptomyces griseus (1). The bacteriological methods used have been described elsewhere $(6,7)$. Aminopeptidase was assayed colorimetrically (2).

Description of Bacillus azotoformans. Bacillus azotoformans (a.zoto.for.mans. French $\mathbf{n}$. azote nitrogen; L. part. adj. formans forming; azotoformans nitrogen forming) ( 0.9 to 1 by 3 to 10 $\mu \mathrm{m})$, have rounded ends, and are rapidly motile by means of numerous long peritrichous flagella. Gram reaction negative. Gram type positive. The cells have thick walls, mesosomes, and persistent septa (6). Aminopeptidase is absent (10). The endospores of this organism are oval ( 1.4 by 2 to $2.5 \mu \mathrm{m}$ ) and make the sporangium bulge; the spores are located terminally or subterminally. Exosporium lacking. Colonies are circular with entire margins, convex, and partially translucent, attaining a diameter of $5 \mathrm{~mm}$ on yeast extract-salts agar. Growth is rapid and 
produces uniform and dense turbidity in yeast extract-salts liquid medium. Poly- $\beta$-hydroxybutyrate is produced when cells are grown in the presence of DL-3-hydroxybutyrate.

Chemoorganotrophic. Growth factors are required. Aerobic metabolism. Glucose is neither fermented nor oxidized. The following respiratory electron acceptors are utilized anaerobically; $\mathrm{NO}_{3}{ }^{-}, \mathrm{NO}_{2}{ }^{-}, \mathrm{N}_{2} \mathrm{O}, \mathrm{S}_{4} \mathrm{O}_{6}{ }^{2-}$, and fumarate. $\mathrm{S}_{2} \mathrm{O}_{3}{ }^{2-}$ is not utilized as an electron acceptor. Considerable quantities of $\mathrm{N}_{2}$ are produced in the course of reduction of $\mathrm{NO}_{3}{ }^{-}, \mathrm{NO}_{2}{ }^{-}, \mathrm{N}_{2} \mathrm{O}$. Oxidase reaction positive.

The following enzymes and electron carriers are present: cytochromes $b$ and $c$; oxidase $a+$ $a_{3}$; nitrate reductase $\mathrm{A}$; nitrite $\left(\mathrm{NO}_{2}^{-} \rightarrow \mathrm{NO}\right)$, nitric oxide $\left(\mathrm{NO} \rightarrow \mathrm{N}_{2} \mathrm{O}\right)$, nitrous oxide $\left(\mathrm{N}_{2} \mathrm{O} \rightarrow\right.$ $\left.\mathrm{N}_{2}\right)$, tetrathionate $\left(\mathrm{S}_{4} \mathrm{O}_{6}{ }^{2-} \rightarrow \mathrm{S}_{2} \mathrm{O}_{3}{ }^{2-}\right)$, and fumarate reductases; and L-glutamate dehydrogenase. The following enzymes are not detected: catalase, thiosulfate reductase, arginine dihydrolase, L-phenylalanine deaminase, urease, and $\beta$-galactosidase.

The following tests are negative: hydrolysis of

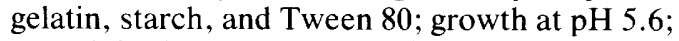
growth in the presence of $5 \% \mathrm{NaCl}, 8 \% \mathrm{KNO}_{3}$, $0.02 \% \mathrm{NaN}_{3}$, and $0.001 \%$ lysozyme; VogesProskauer reaction; indole production; decomposition of tyrosine; production of brown pigment in tyrosine-containing media; decomposition of hippurate with production of benzoate; and conversion of glycerol to dihydroxyacetone.

The following organic acids are degraded: acetate, succinate, DL-lactate, pyruvate, L-malate, citrate, L-glutamate, and L-aspartate. Propionate, glycolate, malonate, glutarate, tartrate, and glycine are not degraded.

The maximum growth temperature is between 42 and $46^{\circ} \mathrm{C}$; no growth occurs at $4^{\circ} \mathrm{C}$.

Lipids comprise 5.7 to $7.4 \%$ of total cell dry weight. Phosphatidylethanolamine is the major phospholipid; cardiolipin and phosphatidylglycerol are also present. The fatty acid composition is as follows: iso- $\mathrm{C}_{14}, 15$ to $30 \mathrm{~mol} \% ; n-\mathrm{C}_{14}$, 2 to $5 \mathrm{~mol} \%$; iso- $\mathrm{C}_{15}, 28$ to $52 \mathrm{~mol} \%$; anteiso$\mathrm{C}_{15}, 16$ to $20 \mathrm{~mol} \% ; n-\mathrm{C}_{15}, 0$ to $1 \mathrm{~mol} \%$ iso- $\mathrm{C}_{16}, 5$ to $8 \mathrm{~mol} \% ; n-\mathrm{C}_{16}, 2$ to $6 \mathrm{~mol} \%$.

Guanine-plus-cytosine content of deoxyribonucleic acid: $39.8 \pm 1.2 \mathrm{~mol} \%$ (as determined by buoyant density in $\mathrm{CsCl}$ ).

Habitat: soils.

Selective isolation can be performed by enrichment culture of pasteurized $\left(10 \mathrm{~min}, 80^{\circ} \mathrm{C}\right)$ soil samples in media containing $1 \%$ BactoPeptone (Difco Laboratories, Detroit, Mich.) incubated at $32^{\circ} \mathrm{C}$ in an atmosphere of pure $\mathrm{N}_{2} \mathrm{O}$.

Type strain: strain $1(=$ ATCC $29788=\mathrm{CCM}$ 2849 = CIP R925).

Description of the type strain. The type strain has all of the characteristics given above for the species. Additional characteristics have been described elsewhere $(6,7)$.

Characteristics distinguishing $B$. azotoformans from related bacteria. $B$. azotoformans differs from Clostridium species by the type of metabolism (aerobic) and the cytochrome content. At present, aerobic, endospore-forming, rodshaped bacteria are classified in the genus Bacillus. A total of 33 species of Bacillus are on the Approved Lists of Bacterial Names (9), but only 10 of these are morphologically similar to $B$. azotoformans; i.e., only 10 species produce oval, subterminal to terminal endospores which distend the sporangium (Bacillus alvei, Bacillus brevis, Bacillus circulans, Bacillus larvae, Bacillus laterosporus, Bacillus lentimorbus, Bacillus macerans, Bacillus macquariensis, Bacillus polymyxa, and Bacillus popilliae). The following nine species grow anaerobically on sugars, produce acid from glucose under aerobic conditions, and therefore differ from $B$. aztoformans: $B$. alvei, B. circulans, B. larvae, B. laterosporus, B. lentimorbus, B. macerans, B. macquariensis, B. polymyxa, and B. popilliae (3-5). Moreover, $B$. macquariensis is a psychrophile that grows only at temperature between 0 and $25^{\circ} \mathrm{C}$ (5). The species most like $B$. azotoformans is $B$. brevis, a strict aerobe that possesses cytochromes $b$ and $c$. However, the neotype strain of B. brevis, strain 52.86 (= ATCC 8246), produces acid from glucose and mannitol under aerobic conditions, hydrolyzes gelatin and tyrosine (4), produces catalase and arginine dihydrolase but not oxidase $a+a_{3}$ or L-glutamate dehydrogenase, and cannot grow anaerobically in the presence of $\mathrm{NO}_{3}{ }^{-}, \mathrm{NO}_{2}{ }^{-}, \mathrm{N}_{2} \mathrm{O}, \mathrm{S}_{4} \mathrm{O}_{6}{ }^{2-}$, or fumarate; in addition, the guanine-plus-cytosine content of $B$. brevis deoxyribonucleic acid is 48 $\operatorname{mol} \%(6,7)$.

\section{LITERATURE CITED}

1. Ballio, A., and S. Barcellona. 1968. Relations chimiques et immunologiques chez les Actinomycetales. I. Les acides gras de 43 souches d'actinomycètes aérobies. Ann. Inst. Pasteur Paris 114:121-137.

2. Cerny, G. 1976. Method for the distinction of gram negative from gram positive bacteria. J. Appl. Microbiol. 3:223-225.

3. Gibson, T., and R. E. Gordon. 1974. Genus I. Bacillus Cohn 1872, p. 529-550. In R. E. Buchanan and N. E. Gibbons (ed.), Bergey's manual of determinative bacteriology, 8th ed. The Williams \& Wilkins Co., Baltimore.

4. Gordon, R. E., W. C. Haynes, and C. Hor-Nay Pang. 1973. The genus Bacillus. Agriculture Handbook 427 U.S. Department of Agriculture, Washington, D.C.

5. Marshall, B. J., and D. F. Ohye. 1966. Bacillus macquariensis $\mathrm{n}$. sp., a psychrotrophic bacterium from sub-antarctic soil. J. Gen. Microbiol. 44:41-46.

6. Pichinoty, F., H. de Barjac, M. Mandel, B. Greenway, and J.-L. Garcia. 1976. Une nouvelle bactérie sporulée, dénitrifiante, mésophile: Bacillus azotoformans n. sp. Ann. Microbiol. (Paris) 127B:351-361.

7. Pichinoty, F., M. Durand, C. Job, M. Mandel, and J.-L. Garcia. 1978. Etude morphologique, physiologique et 
taxonomique de Bacillus azotoformans. Can. J. Microbiol. 24:608-617.

8. Pichinoty, F., M. Mandel, B. Greenway, and J.-L. Garcia. 1977. Isolation and properties of a denitrifying bacterium related to Pseudomonas lemoignei. Int. J. Syst. Bacteriol 27:346-348.
9. Skerman, V. B. D., V. McGowan, and P. H. A. Sneath (ed.). 1980. Approved lists of bacterial names. Int. J. Syst. Bacteriol. 30:225-420.

10. Wiegel, J. 1981. Distinction between the Gram reaction and the Gram type of bacteria. Int. J. Syst. Bacteriol. 31:88. 